DOI https://doi.org/10.32841/2409-1154.2019.43.2.12

Safarova Ze.I., Lecturer

\title{
THE OPINIONS OF RASUL RZA ON THE AZERBAIJANI LANGUAGE
}

Summary. The aim of this article is to bring clarification to some aspects of the linguistic thoughts of the famous Azerbaijani poet Rasul Rza. The author used in his research methods such as descriptions of the characters of the language, a comparative analysis of the linguistic features of languages.

The scientific novelty of this study is that, for the first time, the author classified the linguistic thoughts of the poet Rasul Rza on the reasons for the development of the modern Azerbaijani language and the preservation of national color in it.

It is noted that Rasul Rza had a great merit in the development of his native language and in the enrichment of his vocabulary. As a poet and linguist, he had valuable information about the grammatical structure of his native language. Emphasizing the creativity of Rasul Rza, the author confirms that the search for innovation, selection, substitution, new meaning in the language is especially important for the Azerbaijani writer.

In the conclusion of the article, the author notes that protecting the national identity and the spirit of the mother tongue is a glorious task that encompassed the whole life of Rasul Rza. The author also notes that, according to Rasul Rza, the problem of the native language never loses its relevance. Paying attention to the critical notes of Rasul Rza in newspapers and magazines regarding the problems of the native language, was not unfounded. He gave valuable insight into words that are compatible or incompatible with language laws. Some of his articles are devoted to topical issues of grammar of the native language. There is not a single area of the Azerbaijani language that would not attract the attention of the poet. And because of this, the words and expressions created by him go to the fore and find their embodiment in their native language. The theoretical thoughts of the article are confirmed by facts.

R. Rza's linguistic ideas about the development of the Azerbaijani language have not lost their relevance at present. He noted that the main purpose of language is to develop problems that are crucial for the task of the historical period, through the internal abilities of the language to use all its wealth. R. Rza worked diligently on the language of his works, practiced adherence to the literary language. His poetic, patriotic, ardent, sincere feelings brought wonderful qualities of the native language in the poetry of Azerbaijan.

Key words: Azerbaijani language, linguistics, phrases, problem, Rasul Rza, new words, dialects.

Formulation of the problem. R. Rza, who became famous in the history of national poetry in the twentieth century, entered the literary world with his own individual style of expression and creativity. He, as a poet, brought a new form to Azerbaijani poetry, and was also an active author of objective, topical ideas about linguistic science. R. Rza has done everything possible for the development of linguistic thought in the republic. Throughout his creative activity, he played a major role in ensuring human freedom, ideas of freedom in the Azerbaijani environment, shaping the public consciousness and transmitting these ideas to future generations. The peculiarity of R. Rza's creativity is the ability to add to the word a new content, significance, enrich it with artistic techniques.

Analysis of recent research and publications. R. Rza conducted a thorough analysis to protect the language from the mid20th century. First of all, he tried to enrich the vocabulary of the native language with its internal capabilities. He gave a special impulse to the fact that words from other languages were not used in his literary works or in his scientific and political speeches. Although R. Rza did not mention this in his writings, but it was clearly felt in his work. There is no section of linguistics that would be out of the attention of the poet. He even created new words and phrases, depending on the purpose of the style to describe the events.

The purpose of the article is in addition to his active participation in word-building, he wrote new pages in literary criticism of words and ideas that make sense at all times, and gave us outstanding ideas about the development of our language. The creative work of R.Rza is to use the word in any form, add new meaning to it and enrich it with artistic techniques.

Presenting main material. Rasul Rza in his work "Considerations" focused on linguistic problems and expressed his thoughts in the field of word formation. He sought to find solutions to problems as an expert, stating facts about the wide possibilities of our language. "Why can we say "anmaq" (understand) but not "animll" (understandable)? Why can't we create the word "duyumlu" (sensible) from "duymaq" (to sense)?" [7, p. 49]. The fate of the functioning and preservation of such words, the language cannot be written by pen of several intellectuals. Because the language is the language of the people, and the people should be its protector. Belinsky's words are quoted as "People know what to leave and what to quit." H. Zardabi says: "Language is something that cannot be preserved as before. As everything is over and the tools have changed, the number of new words will grow day by day. Increasing such words does not harm the language; it is useful".

R. Rza expressed her views on how to handle the negative words in the language lexicon, whether it is negative or positive. It focuses on the issue of self-aligning by adapting such words to language rules. "Ohvali-ruhiyyz (mood), rifahi-hal (prosperity), sərf-nəzər (opinion), torcümeyi-hal (autobiography) and some of these words can be replaced by the words in Azerbaijani and will be useful. For example, is it not good to say "dolanacaq" (life) it's place of "rifahi-hal"? The word "guzaran" (life) is also clearer and lively. However, if it works, it lays in our ears" - he said. Until now, the newly created words, based on the national language, have not stopped at the pinnacle of those qualities.

The issue of purity and simplicity in the language is one of the issues that Rasul Rza is worried about and more important. 
Rasul Rza expressed a negative attitude towards the filling of our language with inaccurate words under the influence of the Arabic and Persian languages during the period of the poet's life. For hundreds of years, we have found that all the lexical-grammatical units that keep our souls in our language are considered normal and necessary, with the acquisition of citizenship in our language, compatible with phonetic-grammatical rules of our language.

Importance of words is great in language. The lexical enrichment of the language, the abundance of synonyms, the fullness of meaning and so on. The purchases have their own essence. But the poet objected to the words in the language. He fought not only with unnecessary purchases, but even with them being handpicked by the newspapers. "We must use creatively the supplements that are completely different from the meaning of the word, such as non, anti, obscene, no, bi, and so on, and enrich their application" [7, p. 47].

In R. Rza's opinion, bringing any word of the same word, one or more versions of the word in the language, will not be a service other than damaging it. "Some of the staff of the Communist newspaper can really take the first place by bringing new meaningless words to the language. Even if newspaper workers who have written hundreds of such words natura (натура), uçastok (участок), mexanizator (механизатор), mobilizasiya (мобилизация), sort (copm), pozisiya (позищия), transport (транспорт), spekulyasiya (спекулящия), ekipaj (экипаж), reys (рейс), produksiya (продукция), kоrpus (корпус), ис̧оt (учет), xоrmeyster (хормейстер), avariya (авария), prosent (процент), prostoy (простой), komissariat(комиссариат), masştab (масштаб), realizə etmək (реализовывать), maşinist (машинист), laryok (ларек), struktura (структура), instruksiya (инструкиия), populyarlaşdırmaq (популяризировать) and will give a little effort, they can be found in Azerbaijani language" [7, p. 39].

It is known that science has many subjects that need analysis. Linguistic science has many unresolved topics. According to Rasul Rza, talking about language culture is related to trying to open unresolved problems of that language. Until now, the lack of consistent work about the explanation of the idioms in Azerbaijani language, their historical biography and expression richness disturbed the poet and made interesting and actual ideas about it.

Rasul Rza's profound knowledge of the people led to the reduction of the distance between the nation and the written language by using the facts and the remarkable beauty of all the valuable and rich sources of the source as a workman. From this point of view, he has treated the dialects as a unit of national language and regarded dialects as units that have a positive effect on the artistic quality of the works as a fact which increases the naturalness of the language and strengthens the nationality. But he has been a partner of caution to dialects, preferring to use them at the proper level.

Language is the result of people's labor activity. The main functions of the language are communication, thought and emotionality. It is becoming a public event by forming these features. Therefore, language is always interconnected with and relationships with the society. Dean is the means of expressing emotions and thoughts of emotionally-expressive feelings through communication. In general, language is a means of shaping the spiritual spirit of the people.

In fact, the literary language and its development are understood as the language of written sources and inscriptions.
Sometimes it does not go beyond the language of peoples or states. From language history, the language used in government offices is confidential, non-operative, which in turn hampers speech development and vocabulary enrichment. From this point of view, literary language may have different meanings. Thus, literary language can not be a standard by standard criterion. Demirchizade writes: "... literary language is based on national languages but does not constitute identity with national language, literary language is corrected by the principle of selection and substitution in the national language, for example, the choice of the national language for the composition of the literary language compositions, language, and other words are not acceptable for literary language" [8, p.16].

It seems that the selection and substitution of the national language in the phonetic system were considered norm in the literary language, and the selection and substitution operations in the grammar system were also translated into literary language. It should also be noted that, in the development of literary language, languages are also included in the vocabulary of our language selection and subtitling. It is sometimes used as a synonym word. In general, synonymization in literary language does not enrich the national language.

Selection substitution is a method that guides individual periods, different personalities through individual taste, style, and demand. By means of this method, it determines what dialect, style, and use of words are used. This language tendency has been replaced by someone else at different times over time. Thus, literally, literary language was formed as a scientific language. It can be said that it was derived from religious and philosophical sciences as a source of terms. However, over time, this criterion changed and changed slightly with the words of Azerbaijan. When the language of the 20th century was examined in the 20th century, besides the introduction of national words, supplies from Western European languages were also added. As a result of this process, the formation and enrichment of literary language but also complicated.

The formation of our language at this date is regarded as a real revival period in terms of enriching the vocabulary fund. The use of Arabic-Persian, Turkish-speaking words that are already inactive in the examples of this period has already begun to emerge. New vocabulary and word combinations have begun to appear in the social life of the period. The enrichment of more vocabulary content has enhanced the role of Russian words. These purchases are mainly based on the development of the Azerbaijani literary language. With the expansion of ties and relationships between peoples and the demands of social life, new information has emerged as a new word. These words play an important role in enriching the languages of fraternal peoples.

These processes in the dialectical unity lead to the increase of the words of the national language as well. This rapprochement - as a factor in the expansion of the language relations. One of the tools that influences the development of languages is that of the media - newspapers, radio, and so on plays an important role in the development of literary language, the development of written and spoken words, and the emergence of new words and phrases. Reflecting on everyday events, it also reflects updates on all aspects of life.

From the first half of the 20th century, Azerbaijan's literary language has gained new qualities by finding a true way of development. The state of the language acquired, the measures taken to educate the masses of people, and the application 
of compulsory education played a decisive role. The role of the fiction in the development and formation of the Azerbaijani literary language has played an important role in the acquisition of new qualities. The writers were trying to convey the ideas of love to the homeland by conveying the ideas they propagated to their readers. Of course, taking into account the social status of each era, the motives for the new life, the struggle for a new culture are the main topics of art literature.

G. Ismayilova commented on the creative activity of the period: "Since the 30s, the occurrence of new words by popularization of the national language and the use of the Azerbaijani word-forword means has become increasingly dominant. So, the way we use our own vocabulary includes all the spheres of political, economic life, scientific activity, art, culture" [4, p. 69].

Apparently, social life has played a specific role in the development of literary language and enrichment of vocabulary. The vocabulary fund of our language was enriched by these words, word combinations and phrases. A number of terminological words were subsequently replaced by our equivalent in our language. As a result of this process, the lexicon of the language, along with its internal development, also enriched through the acquisition of citizenship rights.

There have been special services of individual artisans in the development of language. The services of Rasul Rza, who are innovative in thinking of Azerbaijani literature, who have peculiar thinking on many issues of time and life, should be especially emphasized. A. Akhundov writes: "Artistic creativity, especially poetry, does not like it. The poem is just fine when it comes to poetic feelings of new and beautiful expressions" [2, p. 81].

R. Rza is one of the factors that strikes with the beauty and beauty of all the wonders of this valuable and rich source, as an artist who is deeply aware of the people's language. Using these, the distance between the public speaking and the written language has diminished. From this point of view, he has treated the dialects as a unit of national language and regarded dialects as units that have a positive effect on the artistic quality of the works as a fact which increases the naturalness of the language and strengthens the nationality. R. Rza writes: "If these words are not reproduced in the spirit of the mother tongue, in harmony, in the words of the mother tongue, in a word, and in their souls, it enriches the language. And since it comes from the language of another people, without regard to the law and the law of nature" [7, p. 41].

However, he favored the careful attitude of the dialects and preferred them to the proper level. It is known that dialects have a special layout in the language and they also have their own lexicon. And it is also a very valuable fact that the lexicon of dialects is basically national words. According to R. Rza, it is more optimistic to call for dialects than unnecessary purchases. "On the other hand, as it affects Arabic-Persian languages, on the other hand, it participates in the violation of our language. While this magazine should play the most important role of giving us the example of our literary Azerbaijan, it is far behind the development of the native language and shows bad examples" [7, p. 37].

The writer's works in this mainstream of his creativity have a great deal of different words in the spoken language that brings simplicity, naturalism, enrichment of means of expression and styles. The words of this tribe consist of simple, corrective, complex words, frazeological units. Simple, corrective, or complicated words that are used in Rza's language are words expressing concepts related to people's lives.
Conclusions. These ideas of R. Rza have not lost their relevance at present. The main objective of language is to develop issues that are crucial to the task of the period through the internal capacities of the language, to exploit all the riches of the mother tongue. R. Rza, who worked diligently on the language of his works, practiced adherence to the literary language. His poetry, patriotic, fervent, sincere feelings of his poetry have brought remarkable qualities to our language.

\section{References:}

1. Akhundov A. Rasul Rza and mother tongue: Rasul Rza-100 A. Akhundov // Literature Newspaper. 2010. 14th of May. № 19. P. 3-4.

2. Akhundov A. Language and style issues. Baku, 1970.

3. History of literary language of Azerbaijan. Four volumes. IV volume. Baku, "East-West", 2007.

4. Ismayilova G. Status and development of composition composition of Azerbaijan literary language during Sovet period. Azerbaijan literary language history, Part III, Baku, 1982.

5. The problem of the Azerbaijani language in the work of Khalilov B.R. Rza // 525-ci gazet, 2015, 7 february.

6. Hajiyev T. Azerbaijan history of literary language. Baku, "Elm", 2012.

7. Rasul R. Selected works. Five volumes. Volume V. Baku, Leader Publishing House, 2005.

8. Demirchizade A. The style of Azerbaijan language. Baku, 1962.3

Сафарова 3.I. Лінгвістичні роздуми Расул Рзи про азербайджанську мову

Анотація. Метою статті роз'яснити деякі аспекти лінгвістичні міркування відомого азербайджанського поета Расул Рзи. Автор використав у своєму дослідженні такі методи як метод опису характерів мови, порівняльний аналіз лінгвістичних особливостей мов.

Науковою новизною дослідження $€$ те, що вперше автором були класифіковані лінгвістичні роздуми поета Расул Рзи з приводу розвитку сучасної азербайджанської мови, збереження в ній національного колориту.

Расул Рза мав велику заслугу в розвитку рідної мови i збагаченні іiі словникового запасу. Як поет і лінгвіст він мав цінну інформацію про граматичну структуру рідної мови. Підкреслюючи креативність Расул Рза, автор підтверджує, що пошук для інновацій, відбору, заміщення, нового значення в мові особливо важливий для азербайджанського письменника.

У вступній частині статті автор зазначає, що захист національної індентичності і духу рідної мови - завдання всього життя Расула Рзи. Автор вказує, що, на думку Расула Рзи, проблема рідної мови ніколи не втрачала своєї актуальності. Він дав цінне уявлення про слова, які сумісні або несумісні з мовним законом. Деякі його статті присвячені актуальним питанням граматики рідної мови. Не існує жодної області азербайджанської мови, яка не привернула б увагу поета. І з цього створені ним слова і вирази переходять на передній план і знаходять своє втілення в рідній мові. Його теоретичні статті підтверджуються фактами.

Лінгвістичні ідеї Р. Рзи 3 приводу розвитку азербайджанської мови не втратили своєї актуальності. Він зазначав, що основною метою мови є розвиток проблем, які мають вирішальне значення для завдання історичного періоду, через внутрішні можливості мови, щоб використовувати всі іiі багатства. Р. Рза старанно працював над мовою своїх творів, практикував відданість літературній мові. Його поетичні, патріотичні, палкі, щирі почуття принесли чудові якості рідної мови в поезію Азербайджану.

Ключові слова: азербайджанська мова, лінгвістика, фрази, проблема, Расул Рза, нові слова, діалекти. 